\title{
Effects of Concentrations of Micro-alloying Elements and Hot- forging Temperature on Austenite Grain Structure Formed during Carburization of Case-hardening Steel
}

\author{
Genki SAITO, ${ }^{1) *}$ Norihito SAKAGUCHI, ${ }^{1)}$ Munekazu OHNO, ${ }^{1)}$ Kiyotaka MATSUURA, ${ }^{1)}$ Masayoshi TAKEUCHI, ${ }^{2)}$ \\ Taichi SANO, ${ }^{2)}$ Koki MINOGUCHI $^{2)}$ and Takuya YAMAOKA ${ }^{2)}$ \\ 1) Faculty of Engineering, Hokkaido University, Kita 13 Nishi 8, Kita-ku, Sapporo, Hokkaido, 060-8628 Japan. \\ 2) Mitsubishi Steel MFG. Co., Ltd., 1-6 Yawata Kaigandori, Ichihara, Chiba, 290-0067 Japan.
}

(Received on March 6, 2020; accepted on April 30, 2020; J-STAGE Advance published date: June 18, 2020)

\begin{abstract}
Effects of fine precipitates on the austenite $(\gamma)$ grain structures were investigated in JIS SCM420-based case-hardening steels with several different concentrations of the micro-alloying elements and hot-forging temperatures. Micro-alloyed steels of $18 \mathrm{Al}(0.018$ mass $\%$ Al) and $35 \mathrm{Al}-32 \mathrm{Nb}(0.035 \mathrm{mass} \% \mathrm{Al}, 0.032$ mass $\% \mathrm{Nb}$ ) were forging-simulated at $1150^{\circ} \mathrm{C}$ or $1250^{\circ} \mathrm{C}$, normalized at $1070^{\circ} \mathrm{C}$, and carburized at $1050^{\circ} \mathrm{C}$. When the as-received $18 \mathrm{Al}$ steel was normalized and carburized without forging-simulated heating, a uniform $\gamma$ grain structure was observed with the distribution of fine AIN precipitates. However, coarsening of AIN occurred when the forging-simulated temperature was $1150^{\circ} \mathrm{C}$ and it caused abnormal grain growth during carburization. In $35 \mathrm{Al}-32 \mathrm{Nb}$ steel, the same heating did not induce the abnormal grain growth owing to the $\mathrm{AIN}-\mathrm{Nb}(\mathrm{C}, \mathrm{N})$ combined particles. The size of these particles increase with an increase in the forging-simulated temperature. The high forging-simulated temperature caused the dissolution of the fine precipitates, followed by reformation and coarsening of the precipitates during the subsequent cooling and the normalization heating, which resulted in a decreased pinning force and $\gamma$ grain coarsening. Furthermore, TEM observations revealed that a considerable amount of $\mathrm{Nb}(\mathrm{C}, \mathrm{N})$ particles exist near large eutectic MnS particles. Thermodynamic calculations based on the Scheil's condition showed that the formation of these $\mathrm{Nb}(\mathrm{C}, \mathrm{N})$ particles was due to segregation during solidification. It was suggested that such local concentration of the precipitate particles in the last solidifying region leads to ununiform distribution of the pinning force that may induce the abnormal grain growth.
\end{abstract}

KEY WORDS: low alloy steels; case-hardening steels; carburization; forging temperature; austenite grain size; abnormal grain growth; pinning.

\section{Introduction}

Carburization is generally applied to components of transportation equipment such as gears and shafts to improve their fatigue strength and wear resistance. Increase in carburization temperature enables reduction of the processing time and thereby it leads to improvement in productivity and reduction in manufacturing cost. When a carburization depth of $1 \mathrm{~mm}$ is considered, for example, $12 \mathrm{~h}$ is required at a carburization temperature of $930^{\circ} \mathrm{C}$, while it is only $3 \mathrm{~h}$ at $1050^{\circ} \mathrm{C} .{ }^{1)}$ This reduction of the processing time can be applied to an effective production of large components such as those of huge construction equipment, which usually require a longer-time carburization process. However,

\footnotetext{
* Corresponding author: E-mail: genki@eng.hokudai.ac.jp
}

the high-temperature carburization often leads to abnormal grain growth, ${ }^{2,3)}$ which deteriorates the mechanical properties such as fatigue strength and impact resistance.

One of the most commonly used ways for suppressing the abnormal grain growth is the utilization of pinning particles such as $\mathrm{AlN},{ }^{4,5)} \mathrm{Nb}(\mathrm{C}, \mathrm{N}),{ }^{3,4,6-11)} \mathrm{Ti}(\mathrm{C}, \mathrm{N})^{12)}$ and $\mathrm{V}(\mathrm{C}, \mathrm{N}){ }^{13)}$ Carburization combined with cold-forging has often been utilized in manufacturing processes. The occurrence of abnormal grain growth and its mechanism in cold-forged case-hardening steels have been extensively investigated with a focus placed on the effects of shear stress, ${ }^{14)}$ spheroidizing annealing, and dissolution of cementite..$^{15,16)}$ On the other hand, it is also important to clarify the effects of pre-carburization processes such as hot forging and subsequent normalization. Kamada et al. investigated the effect of heat treatment condition including normalization after hot 
forging and found that the differences in the number density and particle size of AIN precipitate greatly affect the $\gamma$ grain structure during pseudo carburization. ${ }^{17)}$ Note that effects of several factors on occurrence of abnormal grain growth remain unclarified. For instance, the hot-forging temperature should affect the size and volume fraction of precipitates and thereby the $\gamma$ grain structures formed during carburization. In addition, it is also important to understand the occurrence and mechanism of abnormal grain growth when multiple micro-alloying elements such as $\mathrm{Al}, \mathrm{Nb}$ and $\mathrm{Ti}$ are considered. Especially, relationship between the abnormal grain growth and a combination of different precipitates remain to be fully elucidated in a quantitative manner.

The aim of this study is to clarify the effects of concentrations of micro-alloying elements and hot-forging temperature on $\gamma$ grain structure formed during carburization of case-hardening steel. In particular, the relationships between the $\gamma$ grain size and the distributions of multiple fine precipitates are investigated in detail. Similar to the previous studies using pseudo-carburizing, ${ }^{3,8,10,11,14,15)}$ this study focuses on the microstructure of the bulk far from the carburized surface. The carburized surface is sometimes suffered from various effects such as decarburization (especially in the case of vacuum carburization), ${ }^{18,19)}$ plastic deformation before carburizing ${ }^{20)}$ and oxidation of elements such as $\mathrm{Si}, \mathrm{Mn}$ and $\mathrm{Cr},{ }^{21)}$ which often result in the abnormal grain growth during carburization. Although these topics are significant to control the grain structure of the surface, this study focuses on the behavior of bulk to enable a basic understanding of the effects of micro-alloying elements and hot-forging temperature without undesired various surface effects. In addition, we focus on the variation of the $\gamma$ grain size at different local positions in the sample caused by solidification segregation.

\section{Experimental Procedures}

Two types of micro-alloyed JIS SCM420 steels of ' $18 \mathrm{Al}$ ' and ' $35 \mathrm{Al}-32 \mathrm{Nb}$ ' were used in this study, and their chemical compositions are summarized in Table 1. The steels were prepared via vacuum induction melting with a capacity of $20 \mathrm{~kg}$ and subsequent hot-rolling into rods with a diameter of $25 \mathrm{~mm}$. Any heat treatment such as annealing was not performed before experiment. Figure 1 shows the heat patterns given to the steels. The as-received steel rod was heated at $1150^{\circ} \mathrm{C}$ or $1250^{\circ} \mathrm{C}$ for $1 \mathrm{~h}$ to simulate the hot forging and then furnace-cooled (F.C.) to room temperature with a cooling rate of $0.6-0.7^{\circ} \mathrm{C} / \mathrm{min}$. A no-heating steel was also prepared for comparison. All these samples were normalized at $1070^{\circ} \mathrm{C}$ for $3 \mathrm{~h}$ and they were then furnace cooled with the same cooling rate written above. To confirm the austenite $(\gamma)$ grain structure formed during the normalization, these samples were also water quenched after normalization of $1070^{\circ} \mathrm{C}$ for $3 \mathrm{~h}$. The furnace-cooled sample after normalization was carburized at $1050^{\circ} \mathrm{C}$ for $5.5 \mathrm{~h}$ under an atmosphere with alcohol and propane, and it was then directly oil-quenched (O.Q.) from the carburization temperature. The heat-treated samples were sectioned in the transverse direction, mechanically polished, and etched using a 4 mass $\%$ picric acid aqueous solution at $50^{\circ} \mathrm{C}$. The prior $\gamma$ grain structure of each section was observed using an optical microscope (VHX-6000, KEYENCE Corp.). To remove the surface effects caused by the pre-carburization process such as decarburization and oxidation, ${ }^{18,19)}$ observed areas far from the carburized area were chosen.

The precipitates in each sample were investigated using a scanning transmission electron microscope (STEM, Titan ${ }^{3}$ G2 60-300, FEI Company). To prepare the STEM sample, a plate-like sample with a thickness of less than $0.5 \mathrm{~mm}$ was sandwiched between two Mo plates using epoxy resin. The use of the Mo plate reduces the volume of $\mathrm{Fe}$ in the TEM sample, thereby reducing the effect of the magnetic force in the TEM chamber. The sandwiched sample was sliced into thin films, which were placed on a Mo singlehole grid. The Mo-grid-supported disc-like samples were polished to a thickness less than $20 \mu \mathrm{m}$ and ion-milled with $5 \mathrm{kV}$ Ar ions by using a precision ion polishing system (PIPS II, model 695, Gatan Inc.). The STEM samples were also prepared using a focused-ion-beam system (FIB, JEM9320FIB, JEOL Ltd.). Blocks with a size of $3 \times 20 \times 15 \mu \mathrm{m}$ were extracted from the sample and attached to the side of the lift-out Mo grid for the FIB. The thickness of the sample was reduced to less than $300 \mathrm{~nm}$ by using a Ga ion. Because it is difficult to distinguish between the contrasts of $\mathrm{Nb}(\mathrm{C}, \mathrm{N})$ and Fe matrix via high-angle annular dark field (HAADF) imaging, energy dispersive spectroscopy (EDS) mapping was employed to investigate the precipitates. A high-probe current of approximately $6 \mathrm{nA}$ was applied for the STEM-EDS mapping, and the results were acquired with an analysis area of $1.8 \mu \mathrm{m} \times 1.8 \mu \mathrm{m}(456 \times 456$ pixels, pixel size of $4 \mathrm{~nm}$ ). The scan duration was 200-400 s per area. Total of 30 and 16 areas were analyzed for the PIPS and FIB prepared samples, respectively. To measure the volume fraction of the precipitates, the sample thickness at each observed area was quantitatively evaluated via electron energy loss spectroscopy (EELS). ${ }^{22)}$ Large precipitates with

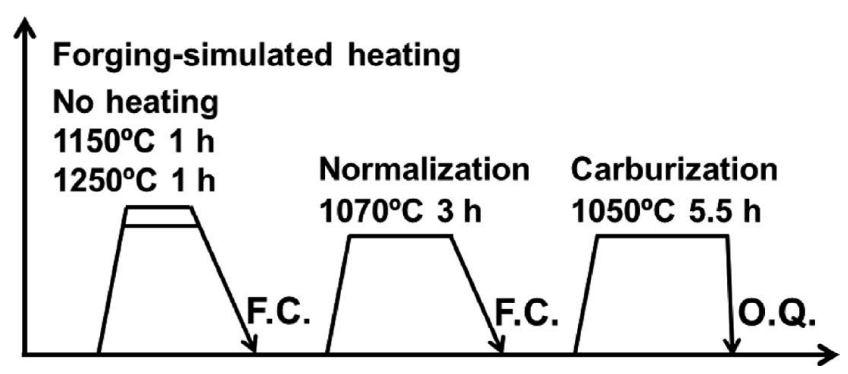

Fig. 1. Heat patterns. F.C. denotes furnace cooling, and O.Q. denotes oil quenching.

Table 1. Chemical compositions (mass \%).

\begin{tabular}{lccccccccccc}
\hline & $\mathrm{C}$ & $\mathrm{Si}$ & $\mathrm{Mn}$ & $\mathrm{P}$ & $\mathrm{S}$ & $\mathrm{Cr}$ & $\mathrm{Mo}$ & $\mathrm{Al}$ & $\mathrm{Nb}$ & $\mathrm{Ti}$ & $\mathrm{N}$ \\
\hline $18 \mathrm{Al}$ & 0.21 & 0.25 & 0.86 & 0.012 & 0.023 & 1.00 & 0.15 & 0.018 & 0.00 & 0.002 & 0.0147 \\
$35 \mathrm{Al}-32 \mathrm{Nb}$ & 0.20 & 0.26 & 0.85 & 0.015 & 0.025 & 0.99 & 0.16 & 0.035 & 0.032 & 0.007 & 0.0250 \\
\hline
\end{tabular}


a size of more than $100 \mathrm{~nm}$ were observed using the scanning electron microscopy technique (SEM, ProX, PhenomWorld B.V.) for each sample. Thermodynamic calculations were performed using the Thermo-Calc software (version 2018b), using the TCFE9 database. ${ }^{23)}$

\section{Results and Discussion}

\subsection{Effects of Hot-forging Temperature and Concen- trations of Micro-alloying Elements}

Figure 2 shows the optical micrographs of the $\gamma$ grain structures obtained under different forging-simulated heating conditions, normalized at $1070^{\circ} \mathrm{C}$ for $3 \mathrm{~h}$ and carburized at $1050^{\circ} \mathrm{C}$ for $5.5 \mathrm{~h}$ followed by oil quenching. The observed area was far from the carburized region, as mentioned in the Experimental Procedures. In the case of the $18 \mathrm{Al}$ steel without forging-simulated heating, a uniform $\gamma$ grain structure with an average size of $47 \mu \mathrm{m}$ forms, as shown in Fig. 2(a1). When the forging-simulated heating at $1150^{\circ} \mathrm{C}$ is performed, a duplex microstructure consisting of fine and coarse $\gamma$ grains appears, shown in Fig. 2(b1). That is, the abnormal grain growth occurred during the carburization in this case. Such a coarse $\gamma$ grain structure also appear in the $18 \mathrm{Al}$ steel obtained for the forging-simulated temperature of $1250^{\circ} \mathrm{C}$, as shown in Fig. 2(c1). It should
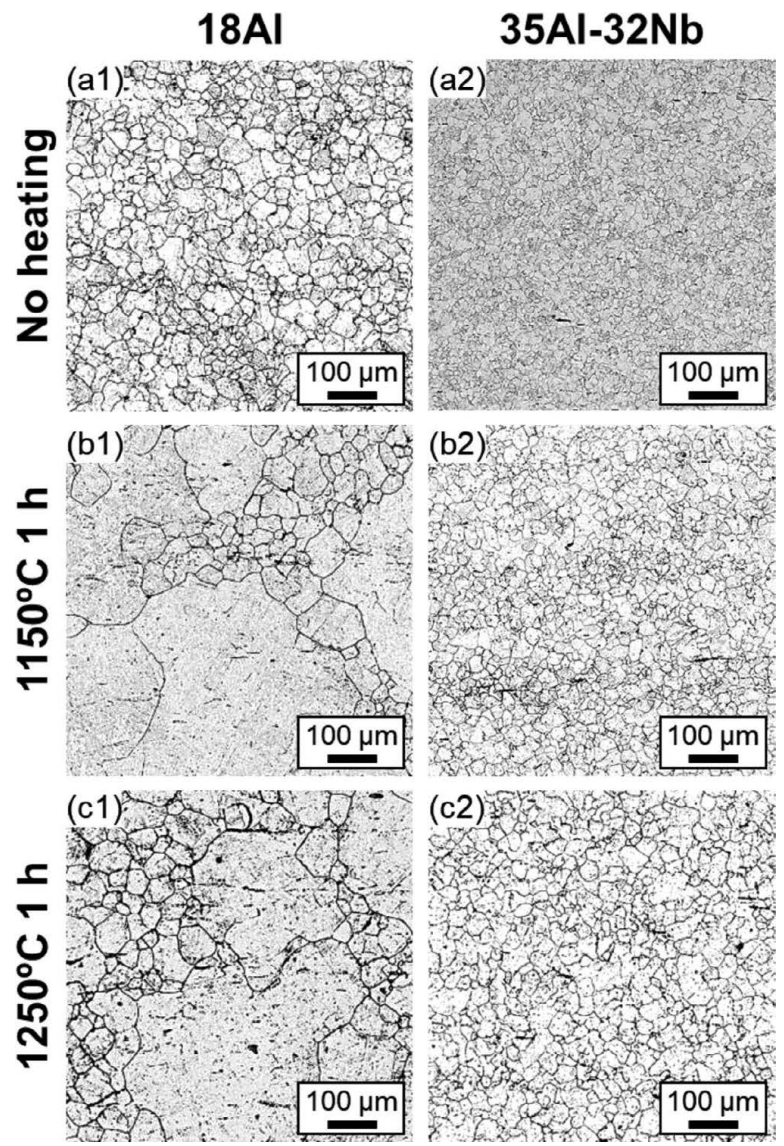

Fig. 2. Optical micrographs of the $\gamma$ grains structure in $18 \mathrm{Al}$ steel (a1, b1, c1) and 35A1-32Nb steels (a2, b2, c2) oil-quenched after normalization at $1070^{\circ} \mathrm{C}$ for $3 \mathrm{~h}$ and the subsequent carburization at $1050^{\circ} \mathrm{C}$ for $5.5 \mathrm{~h}$. Different forging-simulated heating conditions were employed: no heating (a1, a2), heating at $1150^{\circ} \mathrm{C}$ for $1 \mathrm{~h}$ (b1, b2), and heating at $1250^{\circ} \mathrm{C}$ for $1 \mathrm{~h}(\mathrm{c} 1, \mathrm{c} 2)$. The observed areas were far from the carburized region. be noted that the forging-simulated heating affects the final $\gamma$ grain structure during carburization, although the subsequent normalization and carburization treatments are done under the same conditions in all samples including the temperature, holding time, and heating/cooling rates. In the case of the $35 \mathrm{Al}-32 \mathrm{Nb}$ steel, the abnormal grain growth does not occur in all samples regardless of forging-simulated heating condition. Without forging-simulated heating shown in Fig. $2(\mathrm{a} 2)$, the $\gamma$ grain size of the $35 \mathrm{Al}-32 \mathrm{Nb}$ steel was $23 \mu \mathrm{m}$, which is smaller than that of the $18 \mathrm{Al}$ steel. The $\gamma$ grain size increases as the forging-simulated heating temperature increases; they are $28 \mu \mathrm{m}$ and $36 \mu \mathrm{m}$ when the forgingsimulated heating temperatures are $1150^{\circ} \mathrm{C}$ and $1250^{\circ} \mathrm{C}$, respectively, as shown in Figs. 2(b2), 2(c2).

These results can be attributed to the initial microstructures and/or the distributions of pinning particles. Gladman developed a model for predicting the final average grain diameter after grain growth from the initial grain size distribution, the average radius $r$, and volume fraction $f_{\mathrm{V}}$ of the pinning particles, as given in Eq. (1). ${ }^{24,25)}$

$$
\mathrm{D}_{\mathrm{C}}=\frac{\pi}{3} \frac{r}{f_{V}}\left(\frac{3}{2}-\frac{2}{\mathrm{Z}}\right)
$$

$\mathrm{D}_{\mathrm{C}}$ is the predicted average grain diameter, and $\mathrm{Z}$ is the ratio of the maximum grain radius to the average one in the initial microstructure, $R_{\max } / R_{\text {average. }} \mathrm{Z}$ is an index of the initial grain size distribution, and its value is considered to lie between 1.33 and $2{ }^{24)}$ and Hillert's grain growth theory proposes $\mathrm{Z}=1.6{ }^{26)}$ According to this model, the increases in $Z$ and $r$ and/or the decrease in $f_{\mathrm{V}}$ increase $D_{\mathrm{C}}$.

To clarify the effect of initial microstructure, the microstructures before carburization were investigated. Figure 3 shows the optical micrographs of the $\gamma$ grain structures obtained under different forging-simulated heating conditions, normalized at $1070^{\circ} \mathrm{C}$ for $3 \mathrm{~h}$ and followed by water quenching. In the case of the $18 \mathrm{Al}$ steel without forgingsimulated heating shown in Fig. 3(a1), duplex $\gamma$ grain structure forms. For the forging-simulated heating of $1150^{\circ} \mathrm{C}$ and $1250^{\circ} \mathrm{C}$ shown in Figs. 3(b1), 3(c1), coarse $\gamma$ grains appear. Figure 4 shows the optical micrographs of the microstructures obtained under different forging-simulated heating conditions, normalized at $1070^{\circ} \mathrm{C}$ for $3 \mathrm{~h}$ and followed by furnace cooling with a cooling rate of $0.6^{\circ} \mathrm{C} / \mathrm{min}$. Although the all samples have a similar dual phase structure consisting of ferrite and pearlite due to such a slow cooling rate, the size and distribution of ferrite and pearlite grains are different depending on the $\gamma$ grain structures shown in Fig. 3, which are the mother structures of the ferrite-pearlite structures shown in Fig. 4. In the case of 18Al steel without forging-simulated heating shown in Fig. 4(a1), the duplex microstructure with fine and coarse ferrite-pearlite grains forms, which reflects in the duplex $\gamma$ grain structure shown in Fig. 3(a1) because the ferrite nucleus mainly precipitates at $\gamma$ grain boundaries. The coarse ferrite-pearlite structures obtained after the forging-simulated heating of $1150^{\circ} \mathrm{C}$ and $1250^{\circ} \mathrm{C}$ shown in Figs. 4(b1), 4(c1) originate from the coarse $\gamma$ grain structure shown in Figs. 3(b1), 3(c1).

In the case of the $35 \mathrm{Al}-32 \mathrm{Nb}$ steel without the forgingsimulated heating, the $\gamma$ grain structure is fine as shown in Fig. 3(a2) and the corresponding ferrite-pearlite structure after furnace cooling is also fine, as shown in Fig. 4(a2). 

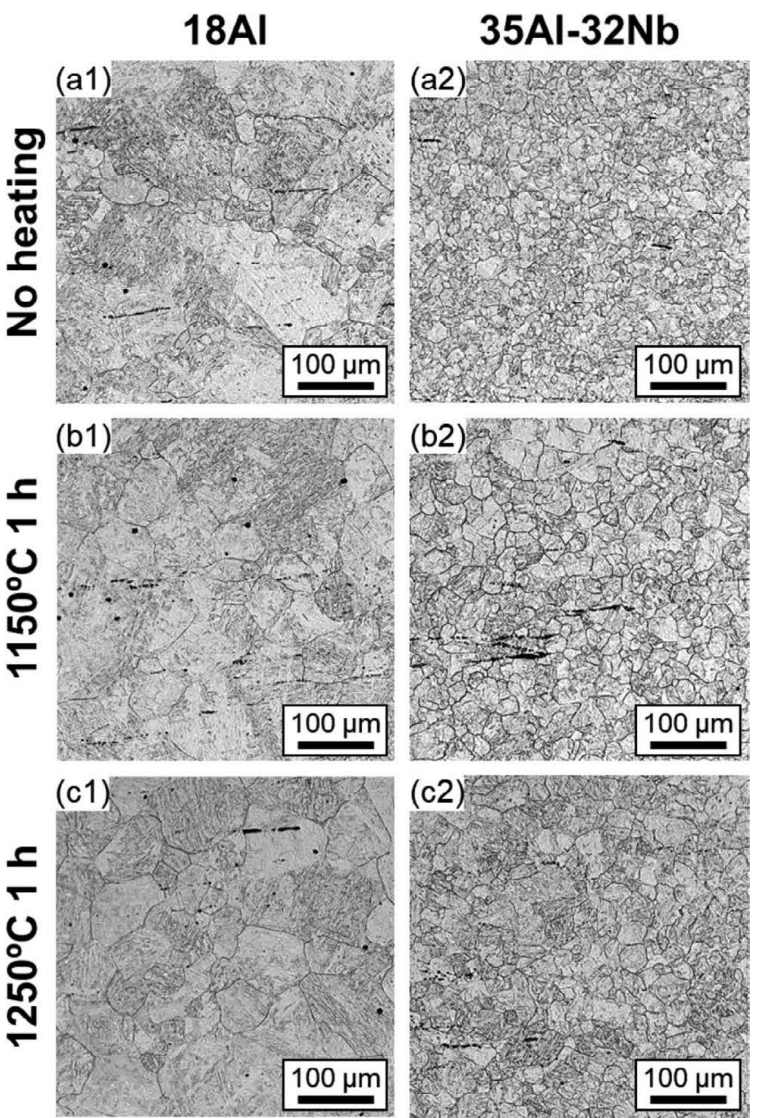

Fig. 3. Optical micrographs of the microstructures in $18 \mathrm{Al}$ steel $(\mathrm{a} 1, \mathrm{~b} 1, \mathrm{c} 1)$ and $35 \mathrm{Al}-32 \mathrm{Nb}$ steel $(\mathrm{a} 2, \mathrm{~b} 2, \mathrm{c} 2)$ after normalization at $1070^{\circ} \mathrm{C}$ for $3 \mathrm{~h}$ and water quenching following different forging-simulated heating condition: no heating, heating at $1150^{\circ} \mathrm{C}$ for $1 \mathrm{~h}$, and heating at $1250^{\circ} \mathrm{C}$ for $1 \mathrm{~h}$.

When the $35 \mathrm{Al}-32 \mathrm{Nb}$ steels are forging-simulated at $1150^{\circ} \mathrm{C}$ or $1250^{\circ} \mathrm{C}$, the $\gamma$ grain structures are relatively larger than that without forging-simulated heating but they are smaller than those compared to $18 \mathrm{Al}$ steels, as shown in Fig. 3. The similar tendency can be seen also in the ferritepearlite structures of $35 \mathrm{Al}-32 \mathrm{Nb}$ steels after furnace cooling, as shown in Figs. 4(a2), 4(b2), 4(c2). It is considered that the $35 \mathrm{Al}-32 \mathrm{Nb}$ steels should contain much amount of precipitates, and therefore, coarsening of the $\gamma$ grains was suppressed during heating at $1070^{\circ} \mathrm{C}$. In summary, it is clear that the forging-simulated heating condition affects the microstructures before carburization. The higher forgingsimulated temperature induces coarse $\gamma$ grain structures during normalization, resulting in coarse ferrite-pearlite structures. Compared to the $18 \mathrm{Al}$ steels, $35 \mathrm{Al}-32 \mathrm{Nb}$ steels suppress the $\gamma$ grains growth. This microstructural diference should be induced by the difference in distributions of the pinning particles.

To clarify the effects of the pinning particles on the $\gamma$ grain structures formed during carburization, the precipitates in the sample after carburization were observed using a TEM. Figure 5 shows the STEM-EDS maps of the samples after carburization. These samples were subjected to different forging-simulated heating conditions, before carburization. Figure 5(a) shows an EDS map of the 18Al steel without forging-simulated heating, in which fine TiN and AlN particles are seen. Although carbon was detected in the TiN particles, the amount was quite small. Figure 5(b)

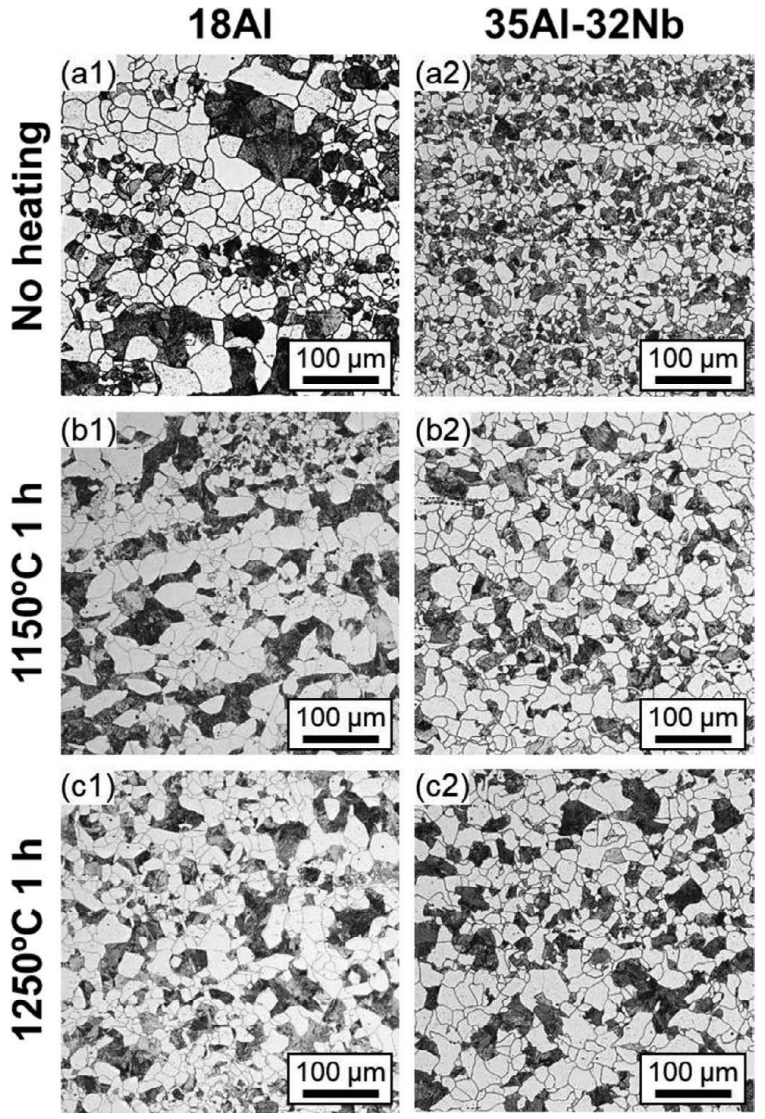

Fig. 4. Optical micrographs of the microstructures in $18 \mathrm{Al}$ steel (a1, b1, c1) and 35A1-32Nb steel (a2, b2, c2) after normalization at $1070{ }^{\circ} \mathrm{C}$ for $3 \mathrm{~h}$ and furnace cooling following different forging-simulated heating condition: no heating, heating at $1150^{\circ} \mathrm{C}$ for $1 \mathrm{~h}$, and heating at $1250^{\circ} \mathrm{C}$ for $1 \mathrm{~h}$.

shows the STEM-EDS map of a sample forging-simulation heated at $1150^{\circ} \mathrm{C}$. The TiN particles are still small, like those in the sample without forging-simulated heating shown in Fig. 5(a), while the AlN particles are larger than those in Fig. 5(a), resulting in the decrease in pinning force and the occurrence of the abnormal grain growth shown in Fig. 2. Figure 5(c) shows an EDS map of the $35 \mathrm{Al}-32 \mathrm{Nb}$ steel obtained for the forging-simulation heated at $1150^{\circ} \mathrm{C}$, where both the TiN and AlN particles are fine. In this sample, $\mathrm{AlN}-\mathrm{Nb}(\mathrm{C}, \mathrm{N})$ combined particles are frequently seen, although isolated $\mathrm{Nb}(\mathrm{C}, \mathrm{N})$ particles are also rarely seen. The TiN particles in this sample contain small amounts of $\mathrm{Nb}$ and $\mathrm{C}$, and $\mathrm{Nb}(\mathrm{C}, \mathrm{N})$ particles also contain $\mathrm{Ti}$ and $\mathrm{N}$ because both the TiN and $\mathrm{Nb}(\mathrm{C}, \mathrm{N})$ have the $\mathrm{NaCl}$ structures. This tendency agrees with the findings in $\mathrm{Ti}$ - and $\mathrm{Nb}$-added steels. ${ }^{12,27)}$ According to the thermodynamic calculation, $\mathrm{Nb}(\mathrm{C}, \mathrm{N})$ consists of $49 \mathrm{~mol} \% \mathrm{Nb}, 1 \mathrm{~mol} \% \mathrm{Ti}, 31 \mathrm{~mol} \%$ $\mathrm{C}$ and $19 \mathrm{~mol} \% \mathrm{~N}$, whereas TiN consists of $45 \mathrm{~mol} \% \mathrm{Ti}$, $5 \mathrm{~mol} \% \mathrm{Nb}, 48 \mathrm{~mol} \% \mathrm{~N}$ and $2 \mathrm{~mol} \% \mathrm{C}$. When the temperature of the forging-simulated heating was increased from $1150^{\circ} \mathrm{C}$ to $1250^{\circ} \mathrm{C}$, the TiN particles are still small, but the AlN- $\mathrm{Nb}(\mathrm{C}, \mathrm{N})$ combined particles are coarsened, resulting in a decreased pinning force and increased $\gamma$ grain growth, as shown in Fig. 2. In summary, increase in the forgingsimulated heating temperature induces the coarsening of the AlN and $\mathrm{AlN}-\mathrm{Nb}(\mathrm{C}, \mathrm{N})$ combined particles, which reduces the pining effect and increase the $\gamma$ grain size.

To understand the origin of the AlN precipitation and 

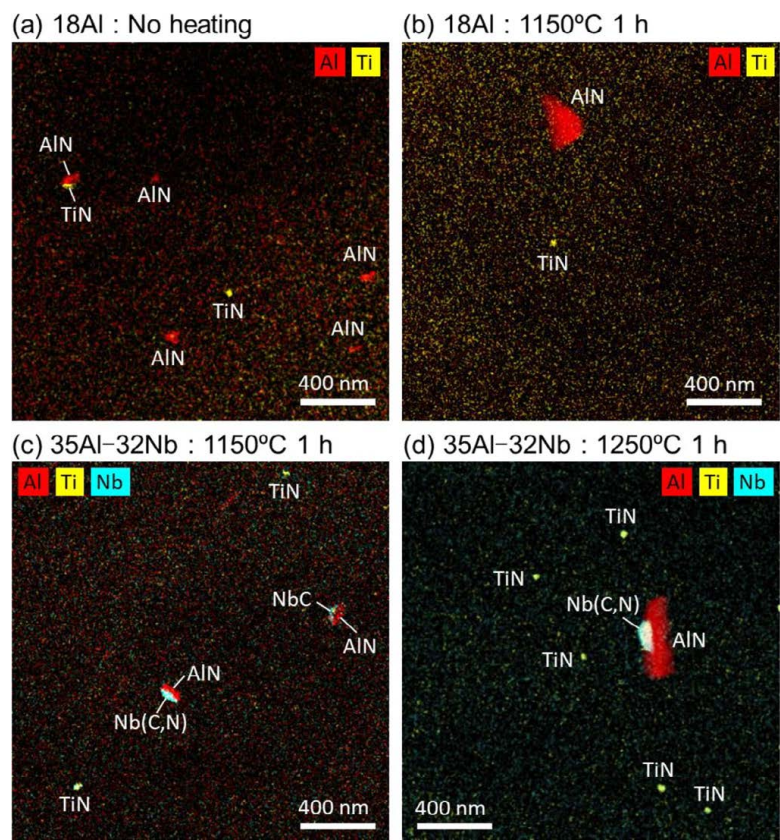

(d) $35 \mathrm{Al}-32 \mathrm{Nb}: 1250^{\circ} \mathrm{C} 1 \mathrm{~h}$

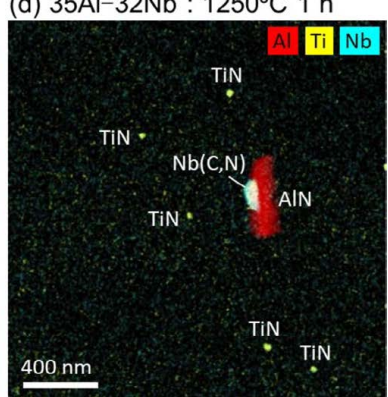

Fig. 5. STEM-EDS maps of the samples after carburization for (a) $18 \mathrm{Al}$ steel without forging-simulated heating, (b) $18 \mathrm{Al}$ steel heated at $1150^{\circ} \mathrm{C}$ for $1 \mathrm{~h}$, (c) $35 \mathrm{Al}-32 \mathrm{Nb}$ steel heated at $1150^{\circ} \mathrm{C}$ for $1 \mathrm{~h}$ and (d) $35 \mathrm{Al}-32 \mathrm{Nb}$ steel heated at $1250^{\circ} \mathrm{C}$ for $1 \mathrm{~h}$. (Online version in color.)

AlN-Nb(C,N) combined particles coarsening observed in the sample of higher forging-simulated heating temperature, the precipitates in the samples before carburization were observed via SEM. Figures 6(a1) and 6(a2) show the SEM images of the as-received samples of $18 \mathrm{Al}$ and $35 \mathrm{Al}-32 \mathrm{Nb}$ steels, respectively. Here, the SEM images correspond to the composition images acquired using a backscattered electron detector. In these images, the particles with a lower average atomic number than that of the Fe matrix, such as the AlN particles, exhibit a darker contrast. Because $\mathrm{Nb}(\mathrm{C}, \mathrm{N})$ particles and the Fe matrix have a similar contrast, it is difficult to find the small $\mathrm{Nb}(\mathrm{C}, \mathrm{N})$ particles in the SEM images. Because AlN particles appear in the as-received samples, it is considered that these precipitates were formed during the hot rolling or annealing process employed to manufacture the steel rods.

The as-received samples were heated to $1150^{\circ} \mathrm{C}$ or $1250^{\circ} \mathrm{C}$ for $1 \mathrm{~h}$ and then water-quenched to investigate the state of the precipitates formed during the forging-simulated heating process. As shown in Figs. 6(b1) and 6(b2), the AlN particles do not dissolve in the Fe matrix when heated at $1150^{\circ} \mathrm{C}$. However, the particles dissolve when heated at $1250^{\circ} \mathrm{C}$, as shown in Figs. 6(c1) and 6(c2). To discuss the dissolution temperature of each precipitate, relationship between the volume fraction of each precipitate and temperature was calculated for the $18 \mathrm{Al}$ and $35 \mathrm{Al}-32 \mathrm{Nb}$ steels. Figure 7(a) shows that the dissolution temperatures of the AlN and TiN in the $18 \mathrm{Al}$ steel are $1100^{\circ} \mathrm{C}$ and $1360^{\circ} \mathrm{C}$, respectively. However, the AlN particles remain undissolved even after forging-simulated heating at $1150^{\circ} \mathrm{C}$ for $1 \mathrm{~h}$ as shown in Fig. 6(b1), which might be because the holding time of $1 \mathrm{~h}$ was not enough for the dissolution of the AlN due to the lower temperature. When heated at $1250^{\circ} \mathrm{C}$, as shown in Fig. 6(c1), AlN particles dissolve. Because the cooling rate in this study was quite low $\left(0.6-0.7^{\circ} \mathrm{C} / \mathrm{min}\right)$,

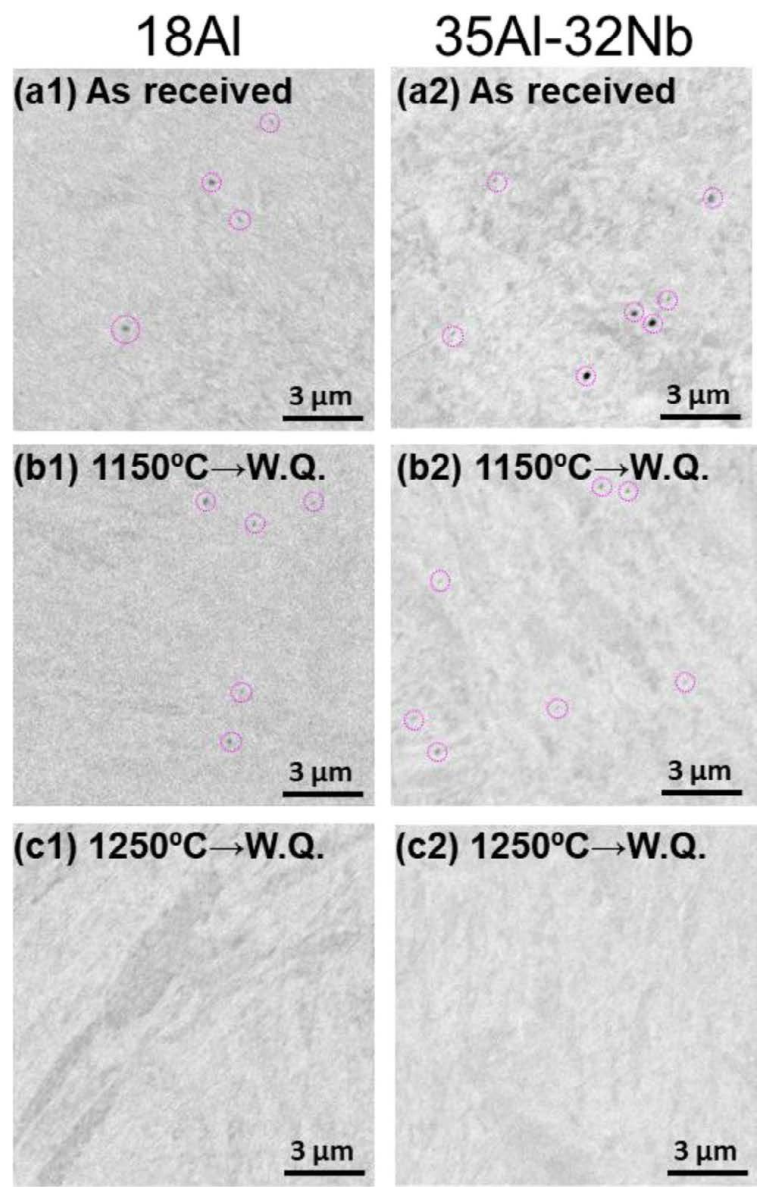

Fig. 6. SEM images of the as-received sample (a1, a2), heated at $1150^{\circ} \mathrm{C}$ for $1 \mathrm{~h}$, subjected to water quenching (b1, b2) and heated at $1250^{\circ} \mathrm{C}$ for $1 \mathrm{~h}$, and finally subjected to water quenching (c1, c2). (Online version in color.)

the coarse AlN precipitates were formed during cooling after forging-simulated heating. In the case of $35 \mathrm{Al}-32 \mathrm{Nb}$ steel, as shown in Fig. 7(b), the dissolution temperatures of $\mathrm{AlN}, \mathrm{Nb}(\mathrm{C}, \mathrm{N})$ and $\mathrm{TiN}$ were $1198^{\circ} \mathrm{C}, 1218^{\circ} \mathrm{C}$, and $1468^{\circ} \mathrm{C}$, respectively. Both the volume fraction and dissolution temperature of AlN are higher in the $35 \mathrm{Al}-32 \mathrm{Nb}$ steel than in the $18 \mathrm{Al}$ steel, which is due to the higher $\mathrm{Al}$ and $\mathrm{N}$ concentrations in the $35 \mathrm{Al}-32 \mathrm{Nb}$ steel, as seen in Table 1. Similarly, the higher Ti concentration in the $35 \mathrm{Al}-32 \mathrm{Nb}$ steel leads to the higher volume fraction and dissolution temperature of TiN. From the calculated results, it can be noted that the AlN particles dissolved at $1250^{\circ} \mathrm{C}$ in the $35 \mathrm{Al}-32 \mathrm{Nb}$ steel. When the steel is subjected to forging-simulated heating at $1250^{\circ} \mathrm{C}$, the $\mathrm{AlN}$ and $\mathrm{Nb}(\mathrm{C}, \mathrm{N})$ particles dissolve, and they may precipitate again during slow cooling and the subsequent normalization processes. Coarsening of AlN and $\mathrm{AlN}-\mathrm{Nb}(\mathrm{C}, \mathrm{N})$ combined particles can occur during the cooling and normalization, which results in the decrease in pining force. Because the dissolution of the precipitate is suppressed at $1150^{\circ} \mathrm{C}$, precipitation of large particles does not occur and fine precipitates remain. Then the decrease in the pinning force may lead to the abnormal grain growth during normalization and subsequent carburization in the $18 \mathrm{Al}$ steel and $\gamma$ grain coarsening in the $35 \mathrm{Al}-32 \mathrm{Nb}$ steel, as seen in Figs. 2, 3 and 4. Because TiN does not dissolve even at $1250^{\circ} \mathrm{C}$, the particle size of TiN did not change considerably. A further investigation 
(a) $18 \mathrm{Al}$

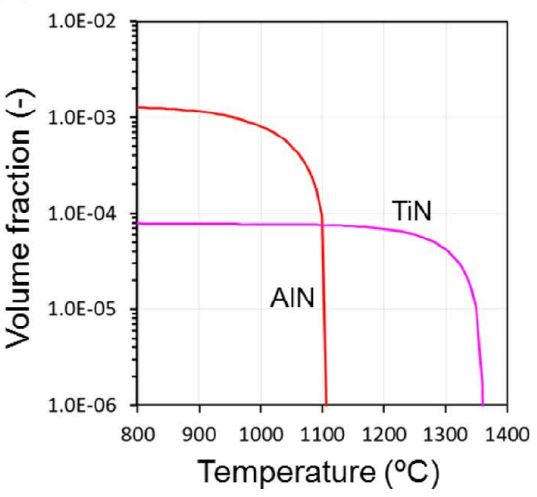

(b) $35 \mathrm{Al}-32 \mathrm{Nb}$

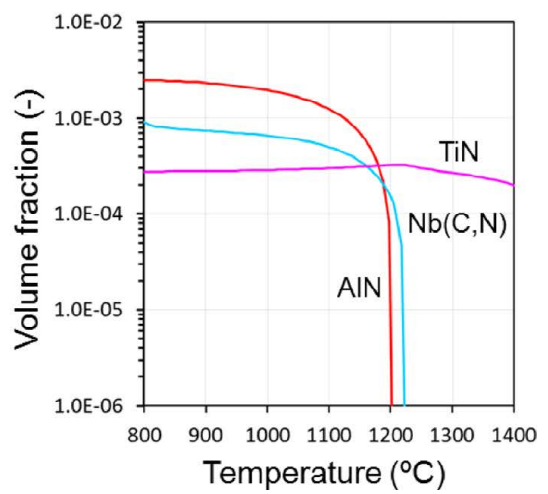

Fig. 7. Volume fraction of each precipitate for (a) $18 \mathrm{Al}$ and (b) $35 \mathrm{Al}-32 \mathrm{Nb}$ steels, determined by performing the thermodynamic calculations. (Online version in color.)

should be aimed at clarifying where and how the AlN and $\mathrm{AlN}-\mathrm{Nb}(\mathrm{C}, \mathrm{N})$ combined particles nucleate during cooling from the forging temperature. It is possible that $\mathrm{Nb}(\mathrm{C}, \mathrm{N})$ particles formed at an early stage act as a nucleation site of AlN particles. In addition, effects of plastic strain during forging on the precipitation should be investigated in a future work because the present experiment focused not on the real hot forging but on the forging-simulated heating. Generally, the recovery and recrystallization occur immediately after and during the forging at high temperatures such as $1150-1250^{\circ} \mathrm{C}$. However, in the manufacturing process, the steel temperature decreases gradually during deformation, and in such situations, strain-induced precipitation can occur at low temperatures. It has been reported that the deformation at $850-950^{\circ} \mathrm{C}$ after solution treatment prompts the $\mathrm{NbC}$ precipitation in a low carbon steel, ${ }^{28)}$ and strain-induced $\mathrm{NbC}$ precipitation occurs at $850-900^{\circ} \mathrm{C}$ in an austenitic $\mathrm{Fe}-30$ mass\% $\% \mathrm{Ni}-0.15$ mass\% $\mathrm{C}$ steel. ${ }^{29)}$

As described above, different kinds of precipitates, i.e., $\mathrm{AlN}$, TiN, isolated $\mathrm{Nb}(\mathrm{C}, \mathrm{N})$, and $\mathrm{AlN}-\mathrm{Nb}(\mathrm{C}, \mathrm{N})$ combined particles are observed in this study. To clarify the influence of each precipitate on the $\gamma$ grain structure separately and quantitatively, the Zener equation was applied, as follows: ${ }^{6,30)}$

$$
d=K \frac{r}{f_{V}}
$$

where, $r$ indicates the average radius of the pinning particles, $f_{V}$ is the volume fraction of the particles, $d$ denotes the average grain diameter, and $K$ is a constant whose value is $4 / 3$ in the original Zener model. In our case, the average radius of each kind of precipitate is quite different. In such a case, the distribution of particle radius should be treated carefully and the pinning pressure $P_{\text {pin }}$ can be expressed by Eq. (3). ${ }^{12,31,32)}$

$$
P_{p i n}=\beta \cdot \sum_{i} \frac{f_{i}}{r_{i}}
$$

This equation is effective when the precipitates have a significantly wide distribution of particle size. In our study, we calculated the pinning forces $\Delta P_{\text {pin }}$ of each kind of precipitate using Eq. (4).

$$
\Delta P_{\text {pin }}=-\frac{3 \sigma}{2}\left(\frac{f_{A l N}}{r_{A l N}}+\frac{f_{N b(C, N)}}{r_{N b(C, N)}}+\frac{f_{T i N}}{r_{T i N}}\right),
$$

where $\sigma$ is the interfacial energy of the $\gamma$ grain boundary, and it was set to $0.5 \mathrm{~J} / \mathrm{m}^{2}{ }^{12,32,33)}$ The terms $f$ and $r$ correspond to the volume fraction and average radius of each particle, respectively, and these values were obtained statistically using a STEM-EDS mapping. Thirty EDS mappings were acquired for each sample, and the sample thickness of each observed area was determined from EELS to calculate the volume of the analyzed part of the sample.

Figures 8(a) and 8(b) show the particle size and the volume fraction of the isolated TiN, isolated $\mathrm{Nb}(\mathrm{C}, \mathrm{N}), \mathrm{AlN}-$ attached $\mathrm{Nb}(\mathrm{C}, \mathrm{N})$ and $\mathrm{AlN}$, respectively; the data for $\mathrm{AlN}$ includes that for isolated $\mathrm{AlN}$ particles and $\mathrm{AlN}-\mathrm{Nb}(\mathrm{C}, \mathrm{N})$ combined particles. AlN has a plate-like morphology, and it is difficult to measure the thickness and diameter of the plate from one image. Thus, the diameter of AlN was determined with an assumption that it has a spherical shape. For the particle size of $\mathrm{AlN}-\mathrm{Nb}(\mathrm{C}, \mathrm{N})$ combined particles, the whole particle body including both the phases was evaluated.

For the $18 \mathrm{Al}$ steel, the particle sizes of the AlN are $69 \mathrm{~nm}$ and $156 \mathrm{~nm}$ in the samples without and with the forgingsimulated heating at $1150^{\circ} \mathrm{C}$, respectively, while TiN has a similar size of approximately $50 \mathrm{~nm}$ for both with and without the heating. Because the volume fraction of TiN is significantly small compared with AlN, as seen in Fig. 8(b), AlN should play a predominant role in the pinning effect. As seen in Figs. 8(a) and 8(b), the forging-simulated hearting increases the pining particle size, while the volume fraction is not strongly affected by the heating for the $18 \mathrm{Al}$ steel, which leads to a decrease in pining force in the sample with the forging-simulated heating at $1150^{\circ} \mathrm{C}$, as shown in Fig. 8 (c). The particle size is larger in the steel with the forgingsimulated heating at $1150^{\circ} \mathrm{C}$, which should be because AlN particles re-precipitate and grow during normalization at $1070^{\circ} \mathrm{C}$. Thus, the abnormal grain growth occurred in $18 \mathrm{Al}$ steel with the forging-simulated heating at $1150^{\circ} \mathrm{C}$, as seen in Fig. 2.

Next, comparison between $18 \mathrm{Al}$ and $35 \mathrm{Al}-32 \mathrm{Nb}$ steels with the forging-simulated heating at $1150^{\circ} \mathrm{C}$ shows that the $35 \mathrm{Al}-32 \mathrm{Nb}$ steel has smaller particle size and larger volume fraction than the $18 \mathrm{Al}$ steel, which leads to larger pinning force in the $35 \mathrm{Al}-32 \mathrm{Nb}$ steel, as seen in Figs. 8(a) to $8(\mathrm{c})$. As seen in Fig. 7(b), although the volume fractions of $\mathrm{AlN}$ and $\mathrm{Nb}(\mathrm{C}, \mathrm{N})$ of the $35 \mathrm{Al}-32 \mathrm{Nb}$ steel decrease with increasing temperature, they do not completely dissolve in $\gamma$ matrix at the forging-simulated hearting temperature of 
(a) Particle size

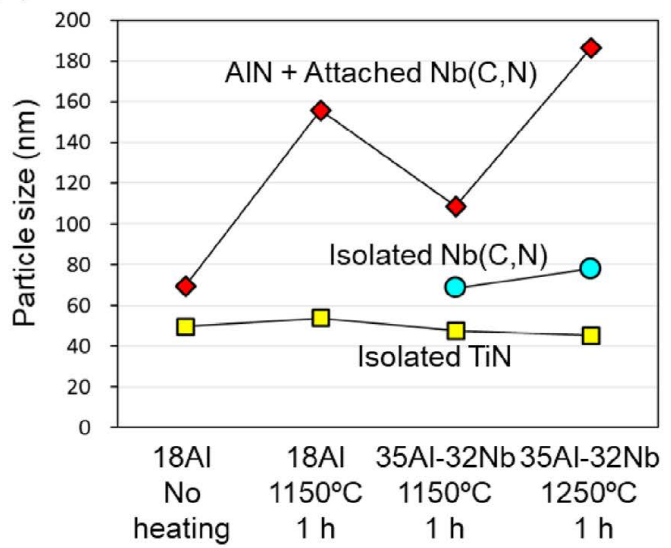

(c) Pinning force

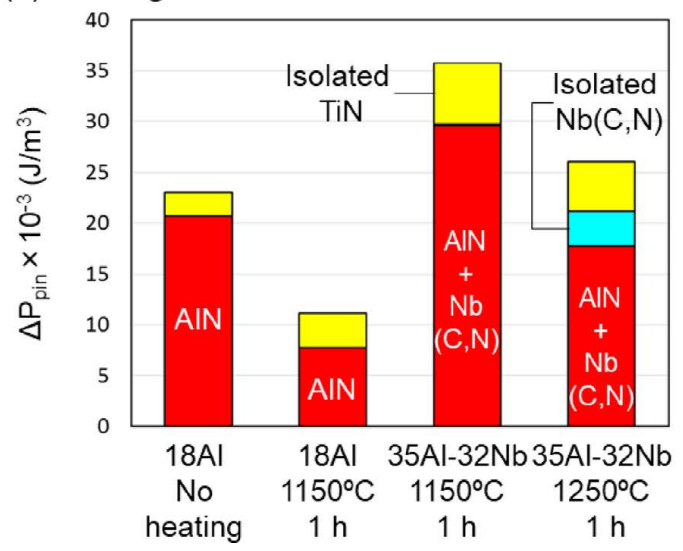

(b) Volume fraction

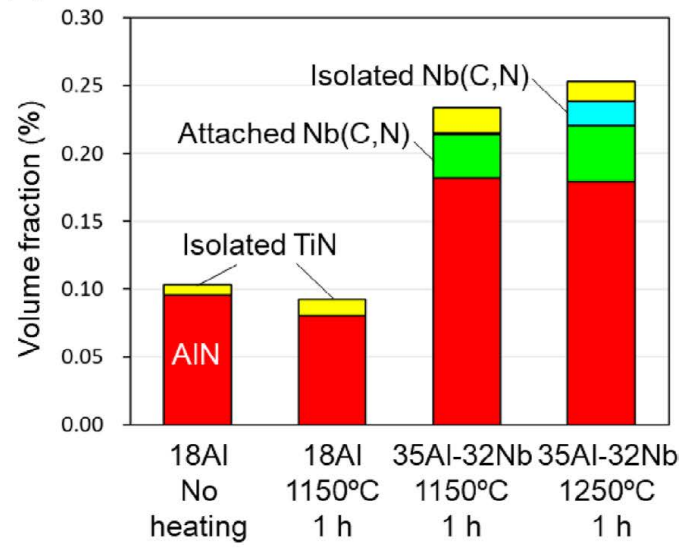

(d) Grain size

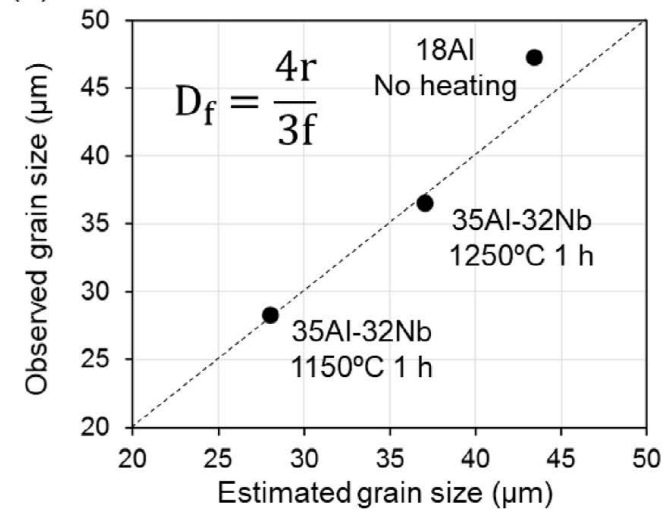

Fig. 8. (a) Particle size, (b) volume fraction, and (c) pinning force of each precipitate in the samples after carburization. (d) Relationship between the observed and estimated values of the $\gamma$ grain size considering the pinning forces. (Online version in color.)

$1150^{\circ} \mathrm{C}$, and great number of particles will still exist. The AlN particles are combined with $\mathrm{Nb}(\mathrm{C}, \mathrm{N})$ particles, as seen in Fig. 5(c). Thus, the grain growth was strongly suppressed in the $35 \mathrm{Al}-32 \mathrm{Nb}$ steel with the forging-simulated heating at $1150^{\circ} \mathrm{C}$, as seen in Fig. 2 .

Finally, comparison of the forging-simulated hearting temperatures between $1150^{\circ} \mathrm{C}$ and $1250^{\circ} \mathrm{C}$ in the $35 \mathrm{Al}-$ $32 \mathrm{Nb}$ steel shows larger particle size and similar volume fraction for $1250^{\circ} \mathrm{C}$, which leads to smaller pining force for the forging-simulated hearting temperature of $1250^{\circ} \mathrm{C}$. As seen in Fig. 7(b), both the AlN and $\mathrm{Nb}(\mathrm{C}, \mathrm{N})$ dissolve in $\gamma$ matrix at $1250^{\circ} \mathrm{C}$. The $\mathrm{AlN}-\mathrm{Nb}(\mathrm{C}, \mathrm{N})$ combined particles re-precipitate and grow during normalization and the pining force decreases, as seen in Figs. 8(a) to 8(c). However, the pining force is much larger in the $35 \mathrm{Al}-32 \mathrm{Nb}$ steels with the forging-simulated heating temperature of $1150^{\circ} \mathrm{C}$ and $1250^{\circ} \mathrm{C}$ than that of $18 \mathrm{Al}$ steel with the forging-simulated heating temperature of $1150^{\circ} \mathrm{C}$, as seen in Fig. 8(c). Thus, the grain growth was strongly suppressed in the $35 \mathrm{Al}-32 \mathrm{Nb}$ steel, as seen in Fig. 2.

We estimated the $\gamma$ grain size from the measured particle size and the volume fraction using the Zener equation (Eq. (2)) with the constant $K=4 / 3$. The estimated grain size was compared with the measured one for different kinds of steel and process conditions, and the results are depicted in Fig. 8(d). The estimated $\gamma$ grain sizes exhibit a reasonable agreement with the measured values. Hence, the evaluated pinning force of each precipitate can be considered quanti- tatively correct.

\subsection{Effect of Segregation}

In this section, we focus on the effect of segregation on the $\gamma$ grain structure. Figure 9(a) shows the microstructure of the $35 \mathrm{Al}-32 \mathrm{Nb}$ steel after being subjected to forgingsimulated heating at $1150^{\circ} \mathrm{C}$. The transverse direction in Fig. 9(a) is same as the hot-rolling direction of the steel rod. In the bottom of Fig. 9(a), there is an area with $\gamma$ grains of small size and some elongated inclusions, indicated as "Fine grains near MnS." These inclusions, which were identified as $\mathrm{MnS}$ by an EDS investigation, are aligned in the rolling direction of the steel rod, as shown in Fig. 9(b). The present steel (JIS SCM420) contains a high level of S concentration to form large eutectic $\mathrm{MnS}$ particles for the machinability purpose. The eutectic reaction, $\mathrm{L} \rightarrow \mathrm{MnS}+\mathrm{Fe}$, occurs in the last solidifying region where coexisting solute elements are segregated to form inclusions during and after solidification, as an $\mathrm{Nb}(\mathrm{C}, \mathrm{N})$ particle is seen in Fig. 9(b). Therefore, the area of fine $\gamma$ grains in Fig. 9(a) corresponds to the last solidifying region. It is considered the formation of fine grains in this area is due to strong suppression of grain growth by the inclusion particles existing in this area. To verify this consideration, we extracted the TEM samples from different areas with the fine and coarse $\gamma$ grains and analyzed them using STEM-EDS mapping.

Figures 10(a) and 10(b) show the STEM-EDS mappings of the areas with fine and coarse $\gamma$ grains, respectively. 
Owing to the limited observation area of the FIB sample, the number of observed AlN particles was insufficient for statistical analysis. Instead, therefore, we focused on the fine
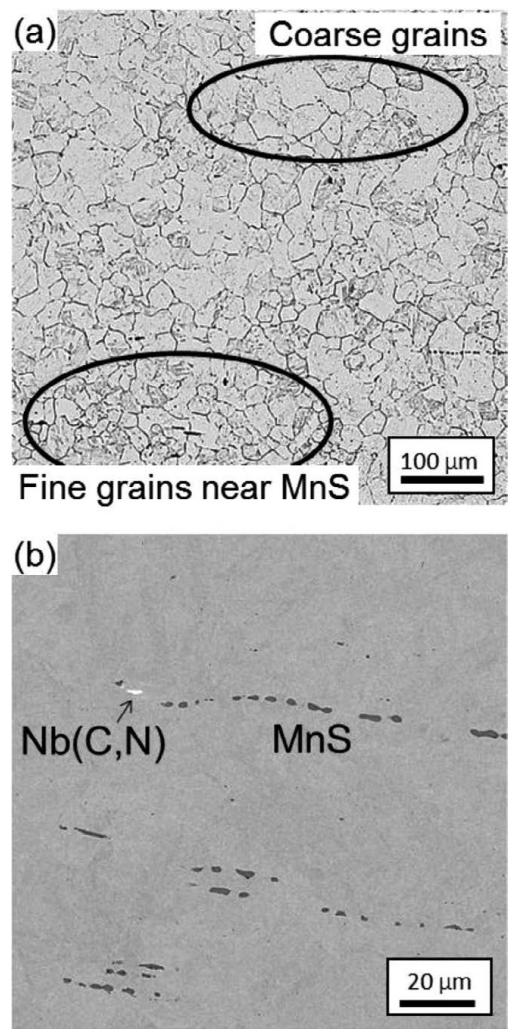

Fig. 9. (a) Microstructure of the $35 \mathrm{Al}-32 \mathrm{Nb}$ steel after forgingsimulated heating at $1150^{\circ} \mathrm{C}$. (b) SEM image of the 35Al$32 \mathrm{Nb}$ steel.
TiN and $\mathrm{Nb}(\mathrm{C}, \mathrm{N})$ particles to discuss the effects of the inclusion particles in the segregated area on the local existence of small $\gamma$ grains. In the area of fine grains, as shown in Fig. 10 (a), a considerable amount of isolated $\mathrm{Nb}(\mathrm{C}, \mathrm{N})$ particles with a size of approximately $75 \mathrm{~nm}$ are formed. In contrast, as shown in Fig. $10(\mathrm{~b})$, the $\mathrm{Nb}(\mathrm{C}, \mathrm{N})$ particles are not seen in the area of coarse grains, although some fine TiN particles are seen there. The size of the TiN particles does not depend on the observed area. The particle size and volume fraction of the inclusions were measured, and the results are summarized in Table 2. These values were used to calculate the pinning force, and the results are shown in Fig. 10(c). It can be noted that the pinning force of the isolated $\mathrm{Nb}(\mathrm{C}, \mathrm{N})$ in the area of fine $\gamma$ grains is significantly high compared to that in the area of coarse $\gamma$ grains owing to the increased volume fraction. It is considered that this difference should be caused by the segregation during solidification.

Figure 11(a) shows the relation between temperature and the phases in the $35 \mathrm{Al}-32 \mathrm{Nb}$ steel, evaluated via thermodynamic calculations based on the Scheil's condition, where the diffusion of the solute elements in the solid is

Table 2. Particle sizes and volume fractions of the $\mathrm{Nb}(\mathrm{C}, \mathrm{N})$ and TiN precipitates at different areas in the $35 \mathrm{Al}-32 \mathrm{Nb}$ steel sample at $1150^{\circ} \mathrm{C}$, measured using the TEM technique.

\begin{tabular}{ccccc}
\hline & \multicolumn{2}{c}{ Particle size $(\mathrm{nm})$} & \multicolumn{2}{c}{ Volume fraction (\%) } \\
\cline { 2 - 5 } & $\begin{array}{c}\text { Isolated } \\
\mathrm{Nb}(\mathrm{C}, \mathrm{N})\end{array}$ & $\begin{array}{c}\text { Isolated } \\
\mathrm{TiN}\end{array}$ & $\begin{array}{c}\text { Isolated } \\
\mathrm{Nb}(\mathrm{C}, \mathrm{N})\end{array}$ & $\begin{array}{c}\text { Isolated } \\
\text { TiN }\end{array}$ \\
\hline Fine grains & 75 & 50 & 0.033 & 0.010 \\
Coarse grains & 89 & 51 & 0.002 & 0.024 \\
\hline
\end{tabular}

(a) Fine grains

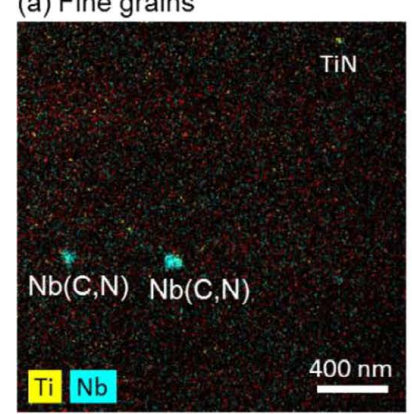

(b) Coarse grains

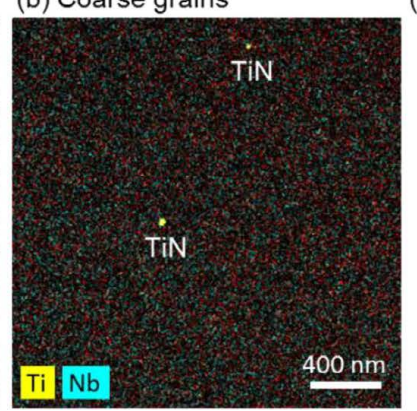

(c) Pinning force

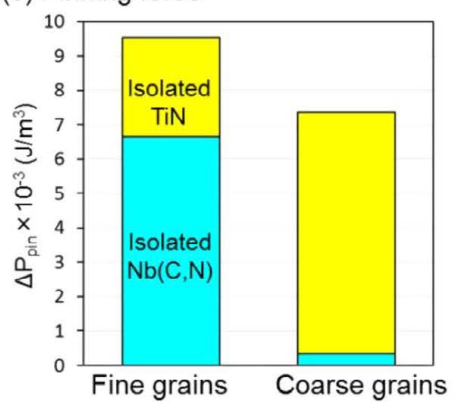

Fig. 10. STEM-EDS maps for areas of (a) fine $\gamma$ grains and (b) coarse $\gamma$ grains, corresponding to those areas shown in Fig. 9(a). (c) Pinning force of each precipitate in the two different areas. (Online version in color.)
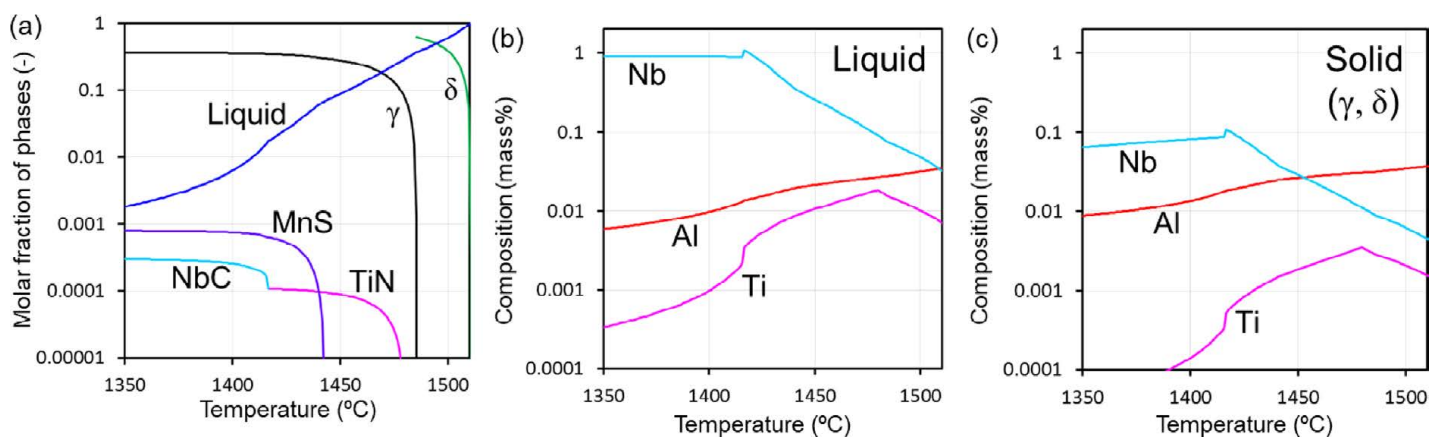

Fig. 11. (a) Relations between temperature and phases for 35Al-32Nb steel, evaluated by performing thermodynamic calculations based on the Scheil's condition. (b, c) Relations between temperature and concentration of solute elements in the liquid and solid. (Online version in color.) 
neglected, while that in the liquid is taken to be infinite. In our calculation, however, the diffusion of $\mathrm{C}$ in the solid was assumed to be infinitely fast because the diffusivity of $\mathrm{C}$ is extremely high compared with other solute elements. When melted steel is cooled, the $\delta$ iron initially crystallizes at $1510^{\circ} \mathrm{C}$ in the liquid phase, and subsequently, the $\gamma$ phase crystallizes at approximately $1485^{\circ} \mathrm{C}$ due to the peritectic reaction. Figures 11(b), 11(c) shows the relation between temperature and the compositions of $\mathrm{Nb}, \mathrm{Al}$ and $\mathrm{Ti}$ in the liquid and solid. As the temperature decreases, the concentrations of $\mathrm{Nb}$ in the liquid and $\gamma$ phases increase significantly until the end of solidification at approximately $1420^{\circ} \mathrm{C}$, and segregation of $\mathrm{Nb}$ occurs at the last solidifying region. Because the last solidifying region contains a high concentration of $\mathrm{Nb}$, a considerable amount of fine $\mathrm{Nb}(\mathrm{C}, \mathrm{N})$ particles can be precipitated during cooling after solidification. In contrast, the concentrations of $\mathrm{Al}$ and $\mathrm{Ti}$ decrease with the decrease in temperature both in the liquid and solid phases. Therefore, the amount of AlN and TiN particles will be smaller in the last solidifying region. This result agrees with the results shown in Fig. 10. Such solidification segregation of micro-alloying elements causes non-uniformity of the pinning force. Such non-uniformity should depend on the solidification structure and the deformation during hot rolling, and it finally affects the $\gamma$ grain structure and occurrence of abnormal grain growth.

\section{Conclusions}

The effects of concentrations of micro-alloying elements and hot-forging temperature on $\gamma$ grain structure were investigated for $18 \mathrm{Al}(0.018$ mass $\% \mathrm{Al})$ and $35 \mathrm{Al}-32 \mathrm{Nb}(0.035$ mass $\% \mathrm{Al}, 0.032$ mass $\% \mathrm{Nb}$ ) case-hardening steels through quantitative analysis of precipitates via TEM, and the results are summarized as follows:

(1) In the case of $18 \mathrm{Al}$ steel, $\mathrm{AlN}$ and $\mathrm{TiN}$ particles are formed, and AlN particles play a predominant role in the pinning effect. In the $35 \mathrm{Al}-32 \mathrm{Nb}$ steels, on the other hand, fine $\mathrm{AlN}-\mathrm{Nb}(\mathrm{C}, \mathrm{N})$ combined particles are mainly formed, which can suppress the abnormal grain growth.

(2) The higher forging-simulated heating causes the dissolution of the fine pinning particles existing in the as-hotrolled steels. The dissolved pinning particles re-precipitates and grow during the subsequent cooling and normalization heating, which results in a decreased pinning force and accelerated $\gamma$ grain coarsening.

(3) The $\gamma$ grain size estimated from the particle size and volume fraction of each precipitate agrees well with the experimentally measured value.

(4) In the last solidifying region, a finer $\gamma$ grain structure forms owing to the presence of a larger amount of fine $\mathrm{Nb}(\mathrm{C}, \mathrm{N})$ particles, which have a high pinning force.

\section{Acknowledgments}

The authors would like to thank Dr. Eng. Mr. Tianlong Zhang, M. Eng. Ms. Yukiko Tanaka, M. MedSc. Ms. Ami Matsuno and Dr. Eng. Ms. Toko Tokunaga for their extensive experimental support. We are grateful to $\mathrm{Mr}$. Kenji Ohkubo, Mr. Ryo Ota, Mr. Takashi Tanioka and Ms. Emiko Obari for their technical assistance with the TEM and
FIB operations. A part of this work was conducted at the Hokkaido University, supported by the "Nanotechnology Platform" Program of the Ministry of Education, Culture, Sports, Science, and Technology (MEXT), Japan.

\section{REFERENCES}

1) M. Kubota and T. Ochi: Mater. Sci. Forum, 539-543 (2007), 4855. https://doi.org/10.4028/www.scientific.net/MSF.539-543.4855

2) R. F. de Morais, A. Reguly and L. H. de Almeida: J. Mater. Eng. Perform., 15 (2006), 494. https://doi.org/10.1361/105994906x124596

3) K. A. Alogab, D. K. Matlock, J. G. Speer and H. J. Kleebe: ISIJ Int., 47 (2007), 307. https://doi.org/10.2355/isijinternational.47.307

4) M. Chapa, S. F. Medina, V. Lopez and B. Fernandez: ISIJ Int., 42 (2002), 1288. https://doi.org/10.2355/isijinternational.42.1288

5) N. Kamiya, Y. Tanaka and R. Ishikura: Denki Seiko, 89 (2018), 3 (in Japanese).

6) C. M. Enloe, K. O. Findley and J. G. Speer: Metall. Mater. Trans. A, 46 (2015), 5308. https://doi.org/10.1007/s11661-015-3103-1

7) N. Zavaleta Gutiérrez, M. I. Luppo and C. A. Danón: ISIJ Int., 47 (2007), 1178. https://doi.org/10.2355/isijinternational.47.1178

8) K. A. AlOgab, D. K. Matlock, J. G. Speer and H. J. Kleebe: ISIJ Int., 47 (2007), 1034. https://doi.org/10.2355/isijinternational.47.1034

9) S. C. Hong, S. H. Lim, K. J. Lee, D. H. Shin and K. S. Lee: ISIJ Int., 42 (2002), 1461. https://doi.org/10.2355/isijinternational.42.1461

10) X. An, Y. Tian, H. Wang, Y. Shen and Z. Wang: Adv. Eng. Mater., 21 (2019), 1900132. https://doi.org/10.1002/adem.201900132

11) T. Murakami, H. Hatano and H. Yaguchi: Tetsu-to-Hagané, 92 (2006), 448 (in Japanese). https://doi.org/10.2355/tetsutohagane1955.92.7 448

12) A. Graux, S. Cazottes, D. De Castro, D. San Martín, C. Capdevila, J. M. Cabrera, S. Molas, S. Schreiber, D. Mirković, F. Danoix, M. Bugnet, D. Fabrègue and M. Perez: Materialia, 5 (2019), 100233. https://doi.org/10.1016/j.mtla.2019.100233

13) R. Staśko, H. Adrian and A. Adrian: Mater. Charact., 56 (2006), 340. https://doi.org/10.1016/j.matchar.2005.09.012

14) T. Fujimatsu, M. Nakasaki, S. Fukumoto and A. Yamamoto: Tetsuto-Hagané, 95 (2009), 161 (in Japanese). https://doi.org/10.2355/ tetsutohagane.95.161

15) Y. Imanami, T. Yamashita, K. Tomita and K. Hase: ISIJ Int., 57 (2017), 2220. https://doi.org/10.2355/isijinternational.ISIJINT-2017-131

16) T. Fujimatsu, K. Hashimoto, K. Hiraoka, S. Fukumoto and A. Yamamoto: Tetsu-to-Hagané, 95 (2009), 169 (in Japanese). https:// doi.org/10.2355/tetsutohagane.95.169

17) Y. Kamada, K. Matsushima and K. Takahashi: Netsu Shori, 58 (2018), 4 (in Japanese). https://doi.org/10.14940/netsushori.58.4

18) Y. Yogo and K. Tanaka: Metall. Mater. Trans. A, 45 (2014), 2834. https://doi.org/10.1007/s11661-014-2233-1

19) T. Ando, T. Morita and K. Inoue: Denki Seiko, 84 (2013), 13 (in Japanese).

20) Y. Eto, M. Umemoto and M. Yoshida: ISIJ Int., 55 (2015), 227. https://doi.org/10.2355/isijinternational.55.227

21) T. Koyama, M. Kubota and S. Yoshida: ISIJ Int., 56 (2016), 1638. https://doi.org/10.2355/isijinternational.ISIJINT-2016-149

22) G. Saito, N. Sakaguchi, M. Ohno, K. Matsuura, M. Takeuchi, T. Sano, K. Minoguchi and T. Yamaoka: ISIJ Int., 59 (2019), 2098. https://doi.org/10.2355/isijinternational.ISIJINT-2019-153

23) Thermo-Calc Software: Thermo-Calc Software TCFE9 Database, Thermo-Calc Software, https://www.thermocalc.com/, (accessed 201810-1).

24) T. Gladman: Proc. R. Soc. Lond., A, 294 (1966), 298. https://doi. org/10.1098/rspa.1966.0208

25) Y. Hou and G. Cheng: ISIJ Int., 58 (2018), 2298. https://doi. org/10.2355/isijinternational.ISIJINT-2017-595

26) M. Hillert: Acta Metall., 13 (1965), 227. http://doi.org/10.1016/00016160(65)90200-2

27) T. Takayama, S. Hinotani, M. Ishikuro, F. Kurosawa, H. Yasuhara, N. Gennai, A. Chino, H. Kutsumi, Y. Giga, Y. Sukenobu, M. Uchiyama and M. Ishii: Tetsu-to-Hagané, 82 (1996), 147 (in Japanese). https:// doi.org/10.2355/tetsutohagane1955.82.2_147

28) S. Akamatsu, Y. Matsumura, T. Senuma, H. Yada and S. Ishikawa: Tetsu-to-Hagané, 75 (1989), 933 (in Japanese). https://doi.org/10.2355/ tetsutohagane1955.75.6_933

29) A. Abdollah-Zedeh and D. P. Dunne: ISIJ Int., 43 (2003), 1213. https://doi.org/10.2355/isijinternational.43.1213

30) N. A. Haroun and D. W. Budworth: J. Mater. Sci., 3 (1968), 326. https://doi.org/10.1007/bf00741970

31) K. Banerjee, M. Militzer, M. Perez and X. Wang: Metall. Mater. Trans. A, 41 (2010), 3161. https://doi.org/10.1007/s11661-0100376-2

32) M. Maalekian, R. Radis, M. Militzer, A. Moreau and W. J. Poole: Acta Mater., 60 (2012), 1015. https://doi.org/10.1016/j.actamat.2011.11.016

33) F. J. Humphreys and M. Hatherly: Recrystallization and Related Annealing Phenomena, Elsevier, Amsterdam, (1995) 283. 